\title{
Sustainable Development of Information Infrastructure of Innovative Acticity
}

\section{Shigabieva A.M.}

\author{
Kazan Federal University, Institute of Management, Economics and Finance, Kazan, 420008, Russia
}

Doi:10.5901/mjss.2015.v6n3p695

\begin{abstract}
The article deals with the main perspective directions of development of the information sphere within innovative activity. Modernization and optimization of indicators of economic growth of Russia during integration of innovative clusters of Russia have to look to study of information - communication technologies and education in the IT sector.
\end{abstract}

Keywords: innovative activity, information infrastructure, innovative cluster, information stream.

\section{Introduction}

Among the perspective directions of development of innovative economy it is necessary to define the directions founded on the state support on various levels of the budgetary streams and mainly in fundamental branches of a national economy - nanotechnology, nuclear power, space.

Effective diversified information component of innovative process in the field of nanotechnologies is not so high-risk since information streams do not touch venture projects, but only infrastructure of an information field.

Development of processes of exchange of information in an innovative key in the sector of processing of raw materials - oil and gas also demands special attention.

Modernization and optimization of indicators of economic growth of Russia during integration of innovative clusters of Russia have to look to the study of information - communication technologies and education in the IT sector that is caused by universal decrease in a multifactorial index of labor productivity and the capital, increase in speed and force of influence scientifically - technical progress which objectification goes deep in investment goods, and also increase of value of skills, knowledge and experience which find the embodiment in labor of high qualification.

Owing to new qualities of economic growth of the world economy based on intensive growth of volume of scientific researches in the sphere of technological, organizational innovations the result of which depends, first of all, on the speed of distribution and modeling of information streams in a scope of innovative products, the advancing dynamics of knowledge intensity in high-tech branches of a national economy leads to transformation of the existing types of economic activity.

Global acceleration of the production which is adjusted on alignment of amplitude of lag from technological progress shifts time intervals of information exchange dynamically - the developing branches from a bigger component of research development, innovations. Absolutely new scientific high-performance directions develop now in parallel and sometimes thanks to the advancing development of the sphere of information technologies, it leads, in turn, to transmitting of the available knowledge, reduction of influence of natural monopolies on development of the corresponding market segments, formation of new market niches.

The economic science has to promote development of interdisciplinary researches, especially in IT sector which main emphasis has to be directed on overcoming of barriers of interaction of scientific divisions and production facilities, thereby reducing financial and temporal lags between scope of research and intra organizational strategic development of the innovative enterprises.

There is an urgent need of formation of the new defining paradigm of economic life of society - information healthy economy of knowledge which characteristic feature have to become filtered by practical realities, only necessary works and skills at creation of new workplaces instead of outdated, "deadlock" information streams [1,2].

Proceeding from modern realities in the era of globalization of the economy which is a subject to information boom, countries seeking to come to the advanced positions in a world rating send efforts to further development and strengthening of information - communication technologies that leads to striking of all of world economic system by information streams, including the state institutes. A result of it is a realization of the principles of the innovative economy which is adjusted by "conductor's baton" of information. 
Information base of the effective innovative sphere directly depends from hierarchically constructed and, that is important, the public structure of knowledge including the triple relations between government institutions, the scientific capacity of universities of the region and scientifically - research base of the enterprise. In the absence of information communications between science and real production at the enterprise, without systematic and equivalent exchange of technologies observance of laws of effective scientifically - technical, innovative policy is impossible.

The tendency of last years of "hiding", "concealment" of innovative practices of the research institutes implementing their activities in corporate associations didn't bring the expected extremely profitable result which served as development of information - consulting projects, merges of databases, information networks - streams with higher educational institutions, scientifically - the research centers for the purpose of obtaining the authentic, updated information on the latest development, technologies.

Major factors of efficiency of innovative activity are presented in Fig. 1.

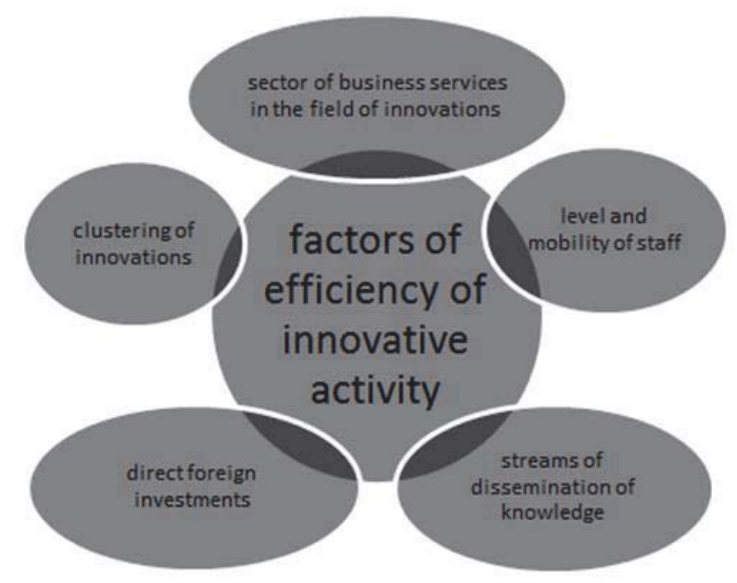

Fig. 1 Factors of efficiency of innovative activity

The market of information at development of innovative activity should be subdivided on market of information itself and the market of services of information sector [3].

It is necessary to distinguish external and internal indicators of potential of growth of information infrastructure at increase of efficiency of innovative activity. (Fig. 2).

Fig. 2 Indicators of information infrastructure growth.

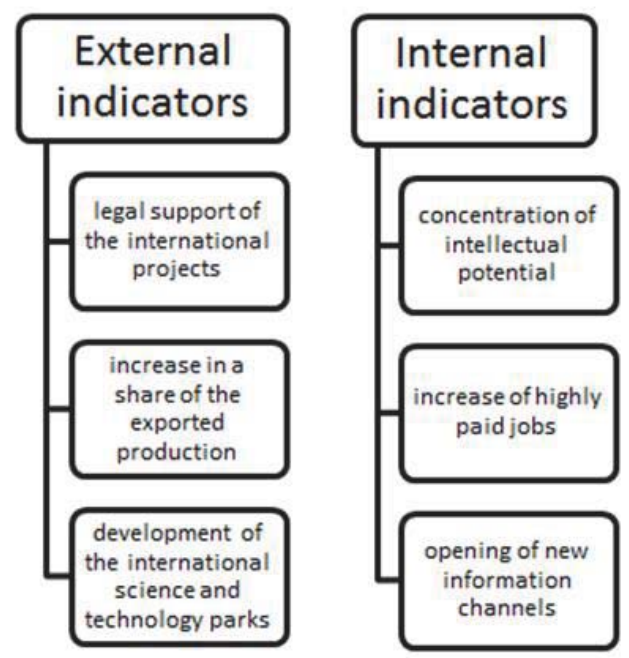

- Optimization of activities for development of the science and technology parks working in the sphere of 
information technologies has to be directed on:

- strengthening of an orientation of activity of science and technology parks on production of export production with the high level of a share knowledge-intensive and information - technological goods and services that means integration of sector of intellectual jobs with the worthy level of payment and continuous improvement of skills and abilities at the rates corresponding to development of the world market of IT - technologies;

- development of the mechanism of support of the companies of federal and regional level entering the world market within grant programs, the subsidizings, credit mechanisms with suspensive percentage payments for encouragement of activity in the sphere of development of innovative products and services directed on smoothing of the price and non price competition on the international scene, reduction of influence of the barriers which are slowing down process of exit of companies to an export orientation of activity;

- optimization of the existing mechanisms of investment injections from the foreign companies in the domestic market of the innovators which are carrying out activity in the sphere of information - communication technologies.

- development of uniform requirements to branch venture financing, for formation of the integrated center of support of development of the information sphere of innovative activity in conditions of state - private partnership.

- creation of fund of branch venture financing with assistance of the state.

- Problems of policy of the state in the field of support and development of information infrastructure of innovative activity are presented in the following form:

- strategic planning of the information sphere in management of the state - development of state and municipal projects in the sphere of information technologies

- strengthening of the centralized interrelation of information and technological infrastructure of the innovative enterprises

- creation of available, open for any Internet user - base with information on activity of the innovative enterprises, including possibility of interactive exchange of information in real time in the "face to face" format.

- a guarantee of safety of activity of the innovative enterprises in the field of the information sphere.

- creation of the certifying centers making an assessment of compliance of the status of the investor and the innovative company.

- connection of the innovative enterprises and potential investors in the virtual market of innovative products with differentiation of access after confirmation of the status of the accredited investor and the status of the innovator by means of the digital signature.

- development of the uniform mechanism of use of information technologies in activity of the public authorities regulating innovative activity for development of information space of the innovative sphere in a tripartite matrix "the state - the innovative enterprises - Higher Education Institutions";

- optimization of system approaches in management of information streams in innovative projects at the state, organizational, personal levels, within the priority directions of development of national economy and innovative sphere;

- creation of uniform system of purchases necessary for effective development of level and security of information technologies in the enterprises which are engaged in innovative activity with granting system of discounts and state support;

- ensuring of the annual centralized control of productivity of optimization of information technologies process, on the basis of the uniform indicators reflecting a condition of information infrastructure of the innovative organizations;

- creation of the integrated educational centers focused on development of educational programs and the subsequent increase of qualification level of employees of IT - sector in the innovative enterprises;

- creation of the free free Internet - base of licensed information products, with free access of the innovative sphere to the organizations, necessary for finishing of the existing information system to a necessary optimum level, by carrying out the express - online - diagnostics of condition of information support of the innovative enterprise;

- improvement of the system of legal support of information infrastructure of innovative enterprises developed on the basis of foreign experience, approached to features of the Russian economic system.

Optimization of information component of innovative activity has to be built proceeding from the existing resource providing the organization and desirable socially - economic effect [4].

3. Criteria and priorities of the information sphere of the organizations - innovators have to be specified annually, 
proceeding from the directions of development of the region in general, in short-term, medium-term and longterm aspects.

4. According to the main directions of administrative reform priorities of use of information technologies in the sphere of public administration are presented in Table 1:

Table 1. Priorities of information technologies use in sphere of public administration of the innovative sphere

\begin{tabular}{|c|c|}
\hline \multirow{4}{*}{$\begin{array}{l}\text { Regulatory base in the field } \\
\text { of information technologies }\end{array}$} & Collecting \\
\hline & Processing \\
\hline & Registration \\
\hline & Distribution \\
\hline \multirow{4}{*}{$\begin{array}{l}\text { Situational centers of } \\
\text { information support }\end{array}$} & Activity modeling \\
\hline & Creation of the centers \\
\hline & Expansion of network interaction \\
\hline & Forecasting of consequences of activity \\
\hline \multirow{3}{*}{$\begin{array}{l}\text { System of the accounting } \\
\text { of information technologies }\end{array}$} & Creation of the recommended criteria indicators with average values on branches of national economy \\
\hline & The analysis of the IT level of the sphere of innovator organization \\
\hline & Development activities for optimization of system of planning \\
\hline \multirow[t]{2}{*}{ Financial mechanism } & Reduction of a share of maintenance costs of innovative enterprises administrative personnel. \\
\hline & Resource base management optimization process \\
\hline \multirow[t]{4}{*}{ Personnel policy } & increase of level of training of employees working in the sphere of information technologies \\
\hline & $\begin{array}{l}\text { creation of base of electronic educational resources for professional development of employees in the } \\
\text { field of IT education }\end{array}$ \\
\hline & accumulation of intellectual potentsil of innovative enterprises \\
\hline & $\begin{array}{l}\text { development of continuous process of transmitting of knowledge and skills within the uniform electronic } \\
\text { environment of interaction }\end{array}$ \\
\hline
\end{tabular}

In the conditions of modern economic realities the state policy in the form of government grants has to be directed on optimization of activity of the science and technology parks which make production in the field of information technologies.

\section{Conclusions}

It is necessary to increase a share of export production of domestic science and technology parks, and also develop new forms of interaction of foreign science and technology parks with domestic, focused on creation of innovative enterprises with tripartite participation of the state, organizations and higher educational institutions.

Allocation of development of information sphere in innovative enterprises as the priority direction , creation of the uniform guarantee fund created from the state grants and voluntary assignments of the innovative enterprises will allow raising the level of the information sphere at the organizations - innovators to the international level, to increase speed of scientific - technical progress.

\section{References}

Tavassoli, S. Innovation determinants over industry life cycle // Technological Forecasting and Social Change, 2015, 91, pp. 18-32.

Bagautdinova, N.G., Galieva, G.T., Pakhmutov, Y.O., Pratchenko, O.V. Methods of regulation of processes of innovation business development // Source of the Document Mediterranean Journal of Social Sciences, 2014, 5 (12), pp. 75-79;

Bulnina, I.S., Askhatova, L.I. Propositions and suggestions addressed to implement the provisions of the Russian federal law No 217 /I Mediterranean Journal of Social Sciences, 2014, 5 (18 SPEC. ISSUE), pp. 129-132;

Kirshin, I.A., Kuzminov, S.V. Evaluation method development for regional economies competitiveness // Mediterranean Journal of Social Sciences, 2014, 5 (18 SPEC. ISSUE), pp. 159-164;

Kundakchyan, R.M., Mokichev, S.D. Methodology of innovative economics // Mediterranean Journal of Social Sciences, 2014, 5 (24), pp. $327-330$

Sarkin, A.V., Bagautdinova, N.G., Averianov, B.A. Development and implementation of adaptive science-intensive manufacture management system based on management processes automation // World Applied Sciences Journal, 2014, 27 (13), pp. 159164

Safiullin, L.N., Shigabieva, A.M., Mazitov, V.M., Saipullaev, U.A. Some methodological foundation of an innovation theory // Life Science 
Journal, 2014, 11 (6 SPEC. ISSUE), pp. 388-391;

Safiullin, L.N., Fatkhiev, A.M., Grigorian, K.A. The triple helix model of innovation // Mediterranean Journal of Social Sciences, 2014, 5 (18 SPEC. ISSUE), pp. 203-206;

Safiullin, L.N., Shaidullin, R.N., Ulesov, D.V., Shigabieva, A.M. Essential features of small and medium business // Life Science Journal, 2014, 11 (6 SPEC. ISSUE), pp. 392-395;

Safiullina, A.M., Odintsova, J.L., Zhilina, N.N., Shamsutdinova, M.R. The main participants of innovation climate development (on the example of the Russian federation) // Mediterranean Journal of Social Sciences, 2014, 5 (18 SPEC. ISSUE), pp. 197-202;

Safiullin L.N., Ismagilova G.N., Safiullin N.Z., Bagautdinova N.G. The development of welfare theory in conditions of changes in the quality of goods and services (2012) World Applied Sciences Journal 18, pp. 144-149. 